\title{
How postmetaphysical can God-talk be?
}

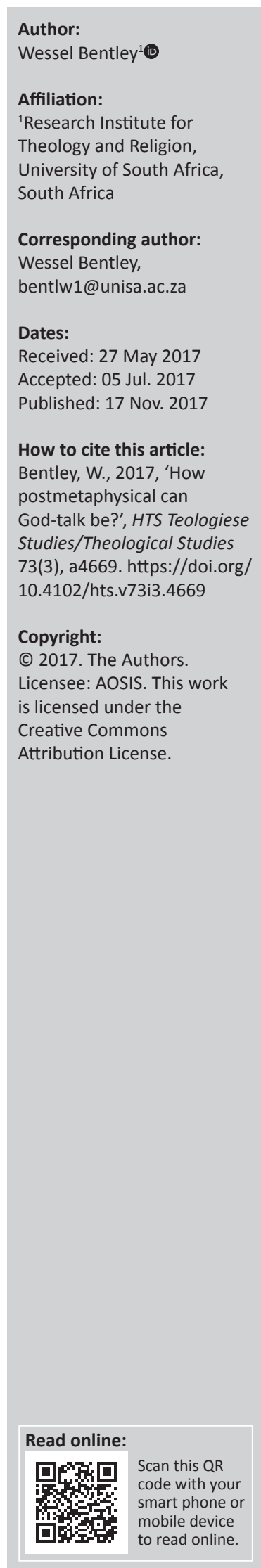

A stalemate often ensues when science, philosophy and theology deliberate over the notion of metaphysics. It is apparent that these three disciplines approach metaphysics from different vantage points. By delineating the definition of metaphysics to the distinction between 'what is known' and 'what is not known', it is argued that the resulting 'silo-effect' of knowledge does not advance the discourse between science, theology and philosophy. This is especially true when religion raises the notion of 'God-talk'. In order to create a common ground between science, theology and philosophy (specifically when it comes to God-talk), this article proposes another construct, namely 'postmetaphysics'. It is argued that postmetaphysics assists in overcoming dualistic theological notions of God which hampers discussions between the mentioned conversation partners.

\section{Introduction}

This article stems from a paper that was presented at a seminar in Pretoria, hosted by the South African Science and Religion Forum. The theme of the seminar was entitled: 'The resurgence of metaphysics in science, philosophy and theology'. Under discussion, was the research problem relating to the renewed interest in metaphysics, especially in the fields of natural science, philosophy and theology. It considered what metaphysics means and how it affects our knowledge, worldviews and belief systems. The research question in this article is surmised in its title: 'How postmetaphysical can God-talk be?' The article approaches the question of metaphysics from a Christian theological perspective and proposes an understanding of the term 'postmetaphysics' as a construct, which contests traditional, dualistic metaphysical God-talk.

It is a daunting task for a theologian to engage in a conversation on the topic of metaphysics with partners such as physicists, philosophers, palaeontologists and mathematicians. ${ }^{1}$ It is a complex conversation, as it is often assumed by natural science (specifically) that the notion of 'metaphysics' is the attempt to turn a blind eye to observable, empirical and logical scientific and philosophical approaches. Metaphysics instead tends to look to external sources for answers to complex questions; one such source which theology refers to is 'God'. ${ }^{2}$ To science, God has been traditionally confined to the meta ${ }^{3}$ of metaphysics, which hampers meaningful conversation between science, theology and philosophy.

Metaphysics in science and philosophy is not necessarily a search for God, thus resulting in a dilemma for theology, which task it is to struggle precisely with the question of God. In this contribution to the interdisciplinary conversation on metaphysics, it would be counterproductive for me as a theologian to engage in a conversation that tries to either prove God's existence or engage in an apologetics for the reason for God. Instead, this article presents an understanding of the term 'metaphysics' and, from a theological perspective, asks how one can engage in God-talk that takes seriously the contributions made by science, theology and philosophy. The hypothesis is that this could be achieved, using another framework, namely 'postmetaphysics'. The point of departure for this article is to demarcate the meaning and ambit of metaphysics. From there, this article will present an approach to God-talk, shaped by the proposed postmetaphysical framework.

1.Of course, other disciplines in the natural and social sciences can be included. The disciplines listed here are those represented at the seminar.

2.Certain scientists argue that the questions and proposed answers offered by 'metaphysical disciplines', such as religion, are not unanswerable by science, but that science simply has not yet got to the point of answering these hypothetical metaphysical problems. Logic dictates that as science answers more and more questions, the realm of metaphysics diminishes, up to an eschatological point where science could possibly provide the elusive 'theory of everything'.

3.The word metaphysics is composed of two parts: the Greek term 'meta-', means 'beyond', and 'physics', refers to that which is encapsulated within the known laws of physics. Metaphysics literally understood, therefore, points to that which is beyond the parameters of the laws of physics. By stating that God has traditionally been confined to the meta of metaphysics, the author means that God and God-talk have, specifically from the perspective of natural science, been understood to be truly outside the parameters set by the laws of physics. God and God-talk are therefore literal metaphysical constructs, with little or no place within the realms of physics. 


\section{Metaphysics and postmetaphysics}

By demarcating a definition of 'metaphysics', it is important to note that metaphysics is neither a stagnant, nor a transdisciplinary homogenous term. It has a rich history shaped by the context, world view and disciplines in which the term has been (and is) employed (see Habermas 1992; Kim \& Sosa 1999). An extreme example is that Aristotelian metaphysics, metaphysics of quantum theory and the metaphysics of 21st century North-American Christian evangelicalism can be hardly understood as meaning the same thing. To assume that metaphysics can or should mean the same across the fields of science, philosophy and theology, would be to do a disservice to the respective disciplines. At the same time, the notion of 'something beyond the parameters of what is known or owned' remains as a common thread.

For now, the following definition of metaphysics needs to suffice: metaphysics is a term used in different disciplines to distinguish between that which is familiar, observable, measurable and understood within the demarcated area of focus in that discipline, and that which lies beyond (see Trigg 2015:3). Such a loose definition is necessary, considering who the conversation partners are, for it is impossible to define the term in any other way that is monolithic. As much as what the seminar aimed for metaphysics to be the common ground on which the conversation partners engage, it could not serve as such, for the divergent interpretations of the term, without being clarified, would only muddy the waters. We have to concede that the common denominator in the conversation between science, philosophy and theology regarding metaphysics is that each brings to the table some admissions. The first admission is that their discipline has a limit to what it knows, while also offering an admission that there is something beyond the reach of its existing knowledge and presuppositions (Trigg 2015:3-15). ${ }^{4}$

Marcelo Gleiser (2014), in his book The Island of Knowledge, illustrates the nature of this kind of metaphysical narrative. Gleiser uses the image of an island, surrounded by a vast ocean, to depict the 'reality' of the limits of knowledge systems. The island represents what we know. ${ }^{5}$ The ocean surrounding the island symbolises the unknown (or yet to be explored). The liminal space ${ }^{6}$ between what is known and that which is not known is always in flux - very much like the ebb and flow of waves on the shore. Sometimes, a knowledge system makes great strides into the unknown, while at other times, knowledge is contested and needs to be reframed in light of emerging insights. Within the domain of the natural sciences, the island therefore represents the laws of physics,

4.See Trigg on the question of whether science has all the answers (Trigg 2015:3-15)

5.Gleiser writes from the perspective of the natural sciences. For the sake of this article, this metaphor can be extended to other fields and deliberately avoids a universal application of the terms 'what is known' and 'what is not known', but rather suggests that there are areas of 'what we know' and 'what we don't know', specifically in the fields of science, philosophy and theology.

6.The boundary of the island is liminal, hard to define, but we know it is there. There is a clear distinction between what is island and what is ocean, but the two seem inseparable. This image of the liminal boundary of the island and ocean must be kept in mind when we discuss the notion of 'dermal metaphysics'. whereas the ocean points to metaphysics. Let us remain in the domain of the natural sciences for a moment.

In the natural sciences, metaphysics refers to that which is considered beyond, or in addition to the realm of physics. Generally speaking, metaphysics in physics follows two lines of philosophical questioning, namely ontology (what is there?) (see Quine 1999) and epistemology (how we know what is there?) (see Russell 1999). It is important to note that metaphysics in physics is not non-physics, pardon the double-negative, but is rather a branch of physics that operates on the boundary of (and beyond) the parameters set by its methodology. The nature of metaphysical enquiry in physics is such that it points to the posing of questions which science itself cannot yet answer by exclusively using the instruments at its disposal. These questions are nonetheless valuable, if not indispensable to the fundamental principles of scientific enquiry. It would be ignorant to assume that these queries are to be considered as 'higher order' questions, as if metaphysics acts as the auditor and gatekeeper of scientific enquiry.

Science is its own measure, not needing a metaphysical construct to assess the validity of physics, but where metaphysics is the inseparable by-product of observation, measurement, prediction and repetition - the indefinable shadow, so to speak, casting itself as a direct consequence (simultaneous manifestation, not as an effect) of scientific enquiry. The metaphysical traits of ontology and epistemology are not foreign to theology or philosophy. The questions of existence, meaning, purpose, identity, causality, consciousness and the list goes on are common questions to the stated conversation partners, and alludes to the natural drive and ability within humanity (and perhaps other levels of complexity) to transcend itself.

Transcendence and metaphysics go hand in hand. Complexity theory and emergence seem to suggest just this; that the parameters of levels of complexity are not an end in itself, but that the transcendence of such boundaries (either by the transfer of information ${ }^{7}$ or the cumulative effect of being) gives rise to higher orders of complexity. These higher orders, while being dependent on the being and laws of lower levels, manifest a new reality with its own set of laws. To translate this into the discussion on metaphysics: The parameters within which science, theology and philosophy individually operate cannot be an end in itself, for if it were, it would create separated islands of knowledge, making it impossible for any meaningful conversation to take place between these disciplines. Metaphysics, without

7.In complexity theory, the identifiable structures in the physical world tend to successfully transcend their boundaries by conveying information to structures outside itself (McKenzie 2011:211-235). An example is intercellular communication. The transfer of information between cells is undergirded by metaphysical principles: Intercellular information sharing presupposes an 'awareness', for lack of a better word, of 'another', and that the function of information transmission is a necessary act, depending on the stimulus which triggered such an 'expression'. Intercellula act, depending on the stimulus which triggered such an 'expression'. Intercellula information sharing is therefore not a metaphysical act, but is undergirded by metaphysical principles (Marcum 2005). The conveyance of information gives rise to the emergence of new levels of complexity, providing the building blocks for new physical parameters in which these more complex systems can operate. Of course this example can be debated from the point of view that intercellular information conveyance is precisely within the ambit of natural physics: 'It is not metaphysics, it is just complex' (Kockenberger et al. 1996). 
transcendence, would then remain the domain of the unknown, the unchartered and the space between disciplines that cannot be bridged.

In a transdisciplinary dialogue, especially that between the natural sciences and theology, the danger of secluding oneself by being fixed in a particular discipline - without taking into consideration the possibilities that exist regarding influences that operate outside the parameters of such a discipline - leads to an assumption that one's own discipline is the custodian of all reality, measurement and observation. The point I am trying to make is that when a discipline operates within the parameters of 'dermal metaphysics', where metaphysics is only considered from within the membrane of a specific discipline with no consideration of multidirectional influences, one is left with an incomplete picture. When we speak about metaphysics in physics, metaphysics in theology and metaphysics in philosophy, the point of eventually coming to a holistic picture of what we are trying to understand cannot be achieved from only within our silo'd disciplines.

It is for this reason that Gould's non-overlapping magisteria (NOMA) (Gould 2002:47-90), although it conveys some truth, is not the whole truth. Yes, it is true that there is a clear distinction between science, theology and philosophy. Each discipline indeed makes its own unique contribution and contains a body of knowledge specific to that discipline, but to suggest that these bodies of knowledge never overlap is inconceivable. If it were isolated, then the dermal metaphysics approach would consider theology as part of physics' metaphysics and vice versa, but this does not do justice to the concept of metaphysics. Again, metaphysics is not nonphysics, neither is metaphysics in physics, religion or philosophy or any other discipline which falls outside the ambit of the natural sciences (see Figure 1).

In the same token, we should not speak about a universalised metaphysics, but a conglomerate of disciplinary metaphysics, which across disciplines sometimes overlaps and sometimes does not. This is represented in Figure 2. In this schematic representation, it is acknowledged that each discipline, each body of knowledge, is a legitimate and identifiable entity. At the same time, it acknowledges that knowledge (what is known) is fluid, while 'what is not known' in a specific discipline may very well fall within the body of knowledge of another. ${ }^{9}$ It would have been helpful to perhaps reserve the term 'metaphysics' to 'physics' and rather speak in other disciplines of metaphilosophy or metareligion or metatheology, but these terms have grown their own identities that do not reflect the essence of what is considered to be metaphysics in the context of this article.

\footnotetext{
8.The term 'dermal metaphysics' is used by Gregersen (2013:395) to describe the human skin as the delineating membrane that defines a person's ontology - that the person is the being within the parameters of their skin. In this context, I adopt this term in a similar way to refer to the hypothetical boundary within which the disciplines of theology, science and philosophy are individually defined.
}

9.Even this figure, as with all representations, is inaccurate, for the fluidity of knowledge is not symmetrical, but like Gleiser's coastline, is in a constant state of flux.

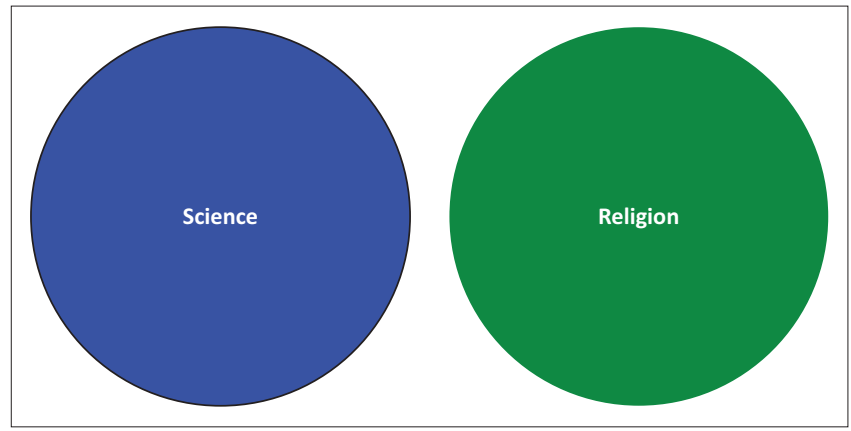

FIGURE 1: A schematic representation of Gould's non-overlapping magisteria.

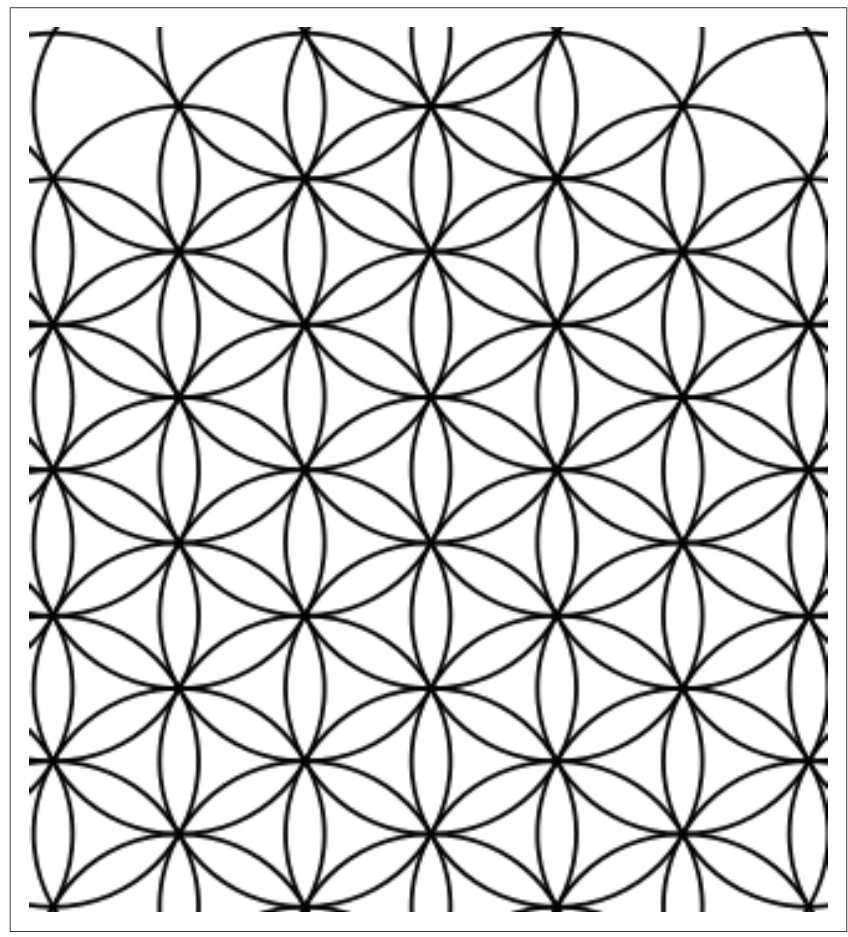

Source: The Flower of Life, n.d., viewed 26 May 2017, from https://www.bibliotecapleyades net/geometria_sagrada/esp_geometria_sagrada_6.htm

FIGURE 2: A schematic representation of a conglomerate of transdisciplinary magisteria. ${ }^{10}$

\section{Proposing a postmetaphysical approach}

The conglomerate of metaphysics is what is meant, as I understand, by Habermas' notion of postmetaphysical thinking. ${ }^{11}$ In the same way as Habermas used the term postsecularism to describe the multifaceted composition of secular society (where space is created for secular, sacred, economic, etc.) (Habermas 2011; Habermas \& Ratzinger 2010:46), so postmetaphysical thinking aims to transcend the

10.This is a modified schematic of 'The Flower of Life' (The Flower of Life n.d.).

11.To get back to Habermas: Habermas uses postmetaphysical in different ways. At first (1980s), he aligned postmetaphysical thinking with posttraditional and postreligious scenarios. Habermas initial view: 'Existing religious institutions and their corresponding world-pictures have a validity only at the level of particular group value orientations, or at the level of what Talcott Parsons calls cultura value standards' (Harrington 2007:58). He challenged religion to the task of value standards (Harrington 2007:58). He challenged religion to the task of transforming theological discourse and identity into a 'universally accessible language' (Harrington 2007:58). In his later work, postmetaphysical thinking takes on other characteristics. Cooke describes it as follows: 'In the present context, the most important feature of postmetaphysical thinking as understoo by Habermas is its agnosticism with regard to the validity of religious beliefs' (Cooke 2006:188), but where religion acts as a partner in the discourse on social development and cohesion. 
delineated parameters of disciplines which define for themselves what it is that falls within their ambit, and that which is extra (Habermas 1992:28-52). This is equally true for science as what it is for religion. As a theologian, I need to admit that religion therefore, sorry to say, does not hold all truth, and neither does philosophy, and nor does science.

Our confidence in truth and that which conveys truth is always shifting. For example, it is interesting to note that philosophy is no longer used as '... a primary source from which new knowledge about human and natural affairs emerges' (Chernilo 2013:265). 'Truth' in modern worldviews seemed to have moved from philosophy and religion to the natural sciences, to that which can be empirically proven. Thus, metaphysics is often rejected on the basis that it refers to previously held truths that are no longer endorsed or considered provable by natural science. This is the error of silo'd, discipline-specific metaphysics. Postmetaphysics, on the other hand, creates the space for the problem of metaphysics to exist, while also accepting that transdisciplinary metaphysics acts as building of a bigger picture (Chernilo 2013:266), an 'emergent knowledge'.

To Habermas (1992), to speak about different disciplines in the context of postmetaphysical theory, there must be a recognition of new convergences across disciplines:

... the debate over the unity of reason in the diversity of its voices; the debate over the position of philosophical thinking in the concert of the sciences; the debate over the esoteric and the exoteric, special science discipline verses enlightenment; finally, the debate over the boundary between philosophy and literature. (p. 9)

As with real-world complexity, the 'dermis' separating disciplines is increasingly difficult to isolate. The distinction between disciplines is analytical in nature (Chernilo 2013:262) and cannot be used as rigid parameters that prohibit meaningful interaction between diverse disciplines, especially the disciplines of science, theology and philosophy. Habermas' postmetaphysical theory points to a universalistic orientation (reality), which implies a move away from reductionist and constructivist projections of the ideal (Chernilo 2013:265). Furthermore, it distances itself from delineating disciplines for the sake of measurable deconstruction, but instead opts for the complexity of life, society, reality and different levels of emergence.

'The modern metaphysical tradition centres on transcendental arguments that grow problematic because of their monological rather than intersubjective foundations' (Chernilo 2013:265) - this needs to be overcome with a postmetaphysical approach. If we acknowledge the fluidity between science and theology, God-talk and empirical science, then the picture is much more fluid, which is the crux of postmetaphysical thinking. This shift is summarised by Cooke (2006):

A ... feature of postmetaphysical thinking ..., is its rejection of ideas of transcendence in a metaphysical, "otherworldly" sense; accordingly, the reference point for its claims to validity is not something beyond human practices and human history, but internal to them'. (p. 188)

\section{On God-talk}

Now to turn to the topic of God-talk. It, according to postmetaphysical theory, is part of the picture, but is not the whole picture. The metaphysical aspect of theology (from the perspective of science) still carries value, even for science. For this reason, speaking about theology, it would be safe to say that 'post-metaphysical' thinking does not necessarily mean 'un-metaphysical' thinking (Harrington 2007:49; MacKendrick 2016:86). Harrington, for instance, argues that when we consider any form of God-talk, we speak about the residue of traditions lingering in worldviews. MacKendrick adds that 'Habermas acknowledges that without the possibility of metaphysics the critique of reason itself becomes suspect' (MacKendrick 2016:86), meaning that the impact of theological metaphysics has made a substantial contribution to where we have developed as a human race. ${ }^{12}$

Habermas, of course, speaks about notions such as metaphysics and postmetaphysical thinking in terms of social structures, from the discipline of sociology, arguing for a postsecular, postmetaphysical approach to social functioning (Habermas 2006). By this, he means that all pockets of society should submit themselves to the reality that they are contributing towards a greater whole (Habermas \& Ratzinger 2010:23). If it were not for society, the different disciplinary voices would not exist. If it were not for the voices, society would not take the shape that it manifests, for all little pockets leave some form of imprint, intertwining with each other, both from within their respective 'disciplines' as well as their influence on each other.

As Habermas speaks about a postmetaphysical way of thinking, the difference between pockets of society implies a form of metaphysics; a delineation between perspectives, groups, even disciplines. Society itself directs us to the liminal point between different pockets of its community, living in their own realities, together contributing towards the emergence of a reality greater than itself (society), and, in turn, society depends on the lower levels of its composition.

But this is not the question asked by this article; it does not ask for a postmetaphysical response from a sociological perspective. The question is a theological question: How postmetaphysical can God-talk be?

First of all, let us consider that 'God-talk cannot evade metaphysical and epistemological considerations' (Moon 2010:107) such as dualism - it naturally tends to draw distinctions between God and the world, whether it implies God's independence or interdependence (Moon 2010:107). Although religion is co-opted into various sectors of society,

12.It is well documented that throughout history, religion, in general, has had a great impact on the development of knowledge systems and worldviews. In a sciencedominated world, it would be irresponsible to relegate religion (and theology in particular) to the irrelevant, simply because it does not use the same a posteriori methodology which science primarily employs. 
the mode of God-talk appears to have remained focused on the dualistic aspects, rather than truly considering its role within the kaleidoscope of information that exists. This is not a new problem. Take, for instance, the God-talk found in the Book of Job, where questions were raised about the origins and response to the physical reality of suffering in Job's life. ${ }^{13}$ God-talk is employed to address an existential reality, but falls into the trap of metaphysical dualism, which is neither helpful to Job nor to a natural science perspective:

Job experiences great loss and discomfort. His wife offers a relief to his suffering: 'Curse God and die' (Job 2:9). His one friend, Eliphaz, explains this suffering and possible response in the light of 'where God strikes, but God also heals' (Job 5:18-27). Another friend, Bildad, explains that Job's children died because they were sinners (Job 8:4). Job's loss is merely a by-product of their just reward, but Job can take heart, because God is on his side, God will not reject the righteous (Job 8:20). Zophar asks Job simply to accept and not to try and explain God's wisdom in allowing these tragedies to happen (Job 11:13-20). Even Elihu, who does not turn to religious reductionism as his predecessors did, but instead seeks wisdom from God for this dilemma, can do no better but to offer a God-talk where God is still outside Job's experienced reality.

The approach by Job's wife and friends proves science's claim that God (and theology) is relegated to the meta of metaphysics. God is not here, but outside reality. To Job's wife, Job should - from within this reality - curse God who is not part of this reality; this will result in his death. To Eliphaz, the God outside is the great mover, the autonomous cause of Job's reality. To Bildad, an external God is offended and brings death, even if it means the subjective experience of suffering by the innocent Job. Zophar also sees God's wisdom as external, imposing itself on the lived experience of Job. Elihu's God-talk also points to God elsewhere. Nowhere do we see a God-talk which suggests that God cries alongside Job or give concrete answers to his misery or a tangible way to cope with his distress. Not once do we witness a God-talk that implies that God's presence can be experienced empathically in the existential, physical reality in which Job finds himself. Metaphysical dualism simply does not seem to work, either in Job's day or today. Yet, it is a God-talk which is rife.

Theological discourse on public platforms still seems to propose the ideas of this kind of dualistic God-talk. To name only a few examples: firstly, that of President Jacob Zuma, who proposes that God is on the side of the ruling party in South Africa (Gallens \& Madia 2017). Secondly, when President Donald Trump places God as the primary mover, to whom his administration looks for guidance (Jalsevac 2017). Thirdly, the South African evangelist, Angus Buchan, who called prayer meetings for God to rescue South Africans from violence, corruption and hate (Botha 2016). In all three

13.The author acknowledges that the problem of theodicy is but one aspect of theology's 'metaphysical' God-talk. Theodicy is used here as an example to illustrate that theology can trip itself up by falling back to silo'd metaphysical dualisms. instances, it is assumed that God is an independent, autonomous entity, who has the ability to take sides with certain groups or people in order to realise their expectations. The proviso for God's interaction may be political affiliation or even certain forms of faith expressions.

These examples are not meant to ridicule or demean these perspectives in any way. It merely seeks to draw our attention to the kind of God-talk that we are witnessing in very public spaces. This kind of dualistic, metaphysical God-talk suggests the following:

- We live in a particular reality - this reality is defined by experience and perceptions of life. It does not take into consideration different levels of complexity that exists, or that the problems perceived in this reality may be interpreted completely differently from other disciplines.

- God, although aware of this reality, is above this reality. God's reality is the reality we should aspire to. It is the reality to which we are to be 'saved'.

- While living in our reality, there needs to be a measure of denying this reality, subjecting this reality to the presence and power of God in order for it to be transformed.

- Through human subjection to God, God's reality starts manifesting in our reality.

To President Zuma, this means that seeing that God is on the side of the people, and the ANC is on the side of the people, the 'permanence' of God is manifested in the 'permanence' of the ANC. Heaven forbid that the ANC should lose an election! For that would mean that the ANC would find itself in the same position as the people of Judah in exile: who sang 'How could we sing the Lord's song in a foreign land?' (Ps 137:4). To the Trump administration, faith is key. Faith in each other, faith in God and then all will be well. To Buchan, prayer is the answer: get together, subject yourself to God in prayer and then God will respond and we will witness God's work.

Exclusive and isolated metaphysical God-talk is a constructed notion. It is imposed by humanity to point to an idealised version of reality, an effort to escape the conflicting, painful experiences of the present realities; a denialism that says: 'This is not how it ought to be', but that there is a 'higher reality' which is the embodiment of our hope of what could be.

This dualism is not helpful. It is grounded in neo-Platonic thought, differentiating between heaven and earth, spirit and flesh, godliness and worldliness and eternity and temporality. This kind of God-talk remains within the silo of theology, imprisoned by the dermis of theological discourse and refuses to be enlightened by the possibility of different knowledge that falls outside its magisterium. The god of dualistic reality cannot empathise for there is no shared reality (Kearney 2010). ${ }^{14}$

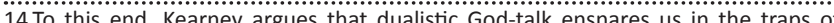
theocracy and theodicy (2010:139). Any God-talk that seeks to understand the world in light of different perspectives, and not only the dualistic metaphysical world in light of different perspectives, and not only the dualistic metaphysical
notions of some forms of theological discourse, needs to come to terms with the notions of some forms of theological discourse, nee
notion that the God of theodicy is dead (2010:167). 
The question postmetaphysical thinking asks is: But what happens when theology (and other disciplines) dares to 'peek over the wall'? ${ }^{15}$ What happens when theology does not dissociate itself from physics or biology or psychology or cosmology, but engages in an earnest and robust conversation of finding the parts of the magisteria that overlap between itself and its knowledge siblings? Of course, theology should acknowledge the unique contribution it can make when its magisterium does not overlap with others. What happens when theology engages in postmetaphysical thinking?

Kearney suggests that religion, not only theology, then meets God (anew): 'The absolute requires pluralism to avoid absolutism' (Kearney 2010:xiv). God presents Godself to us as and in the 'stranger'16 (Kearney 2010:15, 21, 153). This makes God a mystery, and in new ways infinite, omnipresent and omniscient. God then no longer becomes imprisoned in the silo of theology, but the reality of God (postmetaphysically), presents itself as an emergent reality (Moon 2010:107). ${ }^{17}$

Postmetaphysical thinking brings an interesting twist. Where metaphysical God-talk in the discussion between theology and science is characterised by the theologian trying to convert the scientist, it is in postmetaphysical God-talk that the theologian meets God anew through the scientist. Likewise, when the scientist peeks over the wall, theology may provide fresh insights without asking the scientist to abandon their scientific project.

\section{Conclusion}

The conclusion of postmetaphysical God-talk falls within certain new parameters:

- God does not exist as an ontological reality outside physics, philosophy or specifically within theology, but God is experienced when the boundaries of disciplinespecific realities are transcended, leading us to notions such as Gregersen's 'Deep Incarnation' or Kauffman's 'Sacred' (see Kauffman 2008).

- Postmetaphysical God-talk opts for the relational intersection between God and creation. While lending itself to panentheistic forms of God-talk, it moves decisively away from dualism.

- It speaks about God as a recognisable stranger (to theology) - although God evades the confining structures of being 'made real' in lower levels of complexity or exclusively within certain disciplines, there is something transcendentally familiar about Godtalk, which resonates with what we hold as truth and reality in interdisciplinary dialogue. This is not accessed through knowledge alone (which seeks a physical or

15.If we speak about silo'd magisteria, imagine the personification of theology, daring to climb up the wall of its silo and peek over into the magisteria of other disciplines. Further to this, what if theology discovers that there are truths it did not consider before, which, when incorporated into its own knowledge system, allows it to grow?

16.The 'stranger' may, in the context of this article, be the natural sciences, and/or philosophy.

17.Regarding God in level of complexity: Moon argues (1) God as a living system sui generis and (2) God as a meaning system sui generis (Moon 2010:106). metaphysical explanation for God), but surprisingly, through intuition ${ }^{18}$ (see Kearney 2010:198).

How postmetaphysical can God-talk be? The short answer: As much as we want it to be, but we need to guard against the subjective kind of God-talk which trivialises the value of traditional faith expressions. ${ }^{19}$ How postmetaphysical should God-talk be? Well, if theology does not venture to 'look over the wall', it will condemn itself to irrelevance. Responsible God-talk engages all disciplines, not with the purpose of prescribing how God should be found, but discovering that theology itself will find God in places and disciplines where it least expects to find the 'familiar stranger'. ${ }^{20}$

\section{Acknowledgements Competing interests}

The author declares that he has no financial or personal relationships which may have inappropriately influenced him in writing this article.

\section{References}

Botha, C., 2016, '100 000 said to join Angus in prayer in Soweto', Randfontein Herald, viewed 01 March 2017, from http://randfonteinherald.co.za/231667/100-000said-to-join-angus-in-prayer-in-soweto

Chernilo, D., 2013, 'Jurgen Habermas: Modern social theory as postmetaphysical natural law', Journal of Classical Sociology 13(2), 254-273. https://doi. org/10.1177/1468795X13477294

Cooke, M., 2006, 'Salvaging and secularizing the semantic contents of religion: The limitations of Habermas's postmetaphysical proposal', International Journal for Philosophy of Religion 60, 187-207. https://doi.org/10.1007/s11153-006-0006-5

Gallens, M. \& Madia, T., 2017, 'God is on the side of the ANC - Zuma', News24, viewed 01 March 2017, from http://www.news24.com/SouthAfrica/News/god-is-on-theside-of-the-anc-zuma-20170122

Gleiser, M., 2014, The island of knowledge: The limits of science and the search for meaning, Basic Book, New York.

Gould, S.J., 2002, Rocks of ages: Science and religion in the fullness of life, Ballantine Books, New York.

Gregersen, N.H., 2013, 'God, information and complexity: From descriptive to explorative metaphysics', Theology and Science 11(4), 394-423. https://doi.org/1 explorative metaphysics', Theology

Habermas, J., 1992, Postmetaphysical thinking, Polity Press, Cambridge.

Habermas, J., 2006, Times of transition, transl. E. Mendieta, Polity Press, Cambridge.

Habermas, J., 2011, "The Political": The rational meaning of a questionable inheritance of Political Theology', in E. Mendieta \& J. VanAntwerpen (eds.), The power of religion in the public sphere, pp. 15-33, Columbia University Press, New York.

Habermas, J. \& Ratzinger, J., 2010, The dialectics of secularization: On reason and religion, Ignatius Press, San Francisco, CA.

Harrington, A., 2007, 'Habermas's Theological turn?', Journal for the Theory of Socia Behaviour 37(1), 45-61. https://doi.org/10.1111/j.1468-5914.2007.00321.x

Jalsevac, S., 2017, 'Trump brings God back into federal government after long absence', LifeSiteNews, viewed 01 March 2017, from https://www.lifesitenews. com/blogs/trump-brings-god-back-into-government-after-long-absence

Kauffman, S., 2008, Reinventing the sacred: A new view of science, reason and religion, Perseus Books, New York.

Kearney, R., 2010, Anatheism: Returning to God after God, Columbia University Press, New York.

Kim, J. \& Sosa, E. (eds.), 1999. Metaphysics: An anthology, Blackwell Publishing Limited, Oxford.

18.The operations (via the medium of consciousness) of psychic systems or the operations (via communication) of social systems are real, just as the operations (via life) of organic systems are real' (Moon 2010:107).

19.'Systematic theology without science and philosophical reflection may risk being blinded by tradition, but philosophical theology without the historical resources of religious traditions also risk becoming empty' (Gregersen 2013:417).

20.'Therefore one can speak of a postmetaphysical approach. Theo-logy is one such inscription if it is understood as an attempt to understand or think or talk (logos) about God (theos), unless God is interpreted (inscribed) differently' (Meylahn 2014:4) 
Kockenberger, W., Komor, E., Orlich, G. \& Weig, G., 1996, 'Phloem loading - Not metaphysical, only complex: Towards a unified model of phloem loading', Journal metaphysical, only complex: Towards a unified model of phloem loading, Journa of Experimental Botany, 47(Special Supplement), 1155-1164. https://doi.
org/10.1093/jxb/47.Special Issue.1155

MacKendrick, K.G, 2016, 'Postmetaphysical thinking and the philosophy of religion' Method and Theory in the Study of Religion 28, 84-97. https://doi. org/10.1163/15700682-12341353

Marcum, J.A., 2005, 'Metaphysical presuppositions and scientific practices: Reductionism and organicism in cancer research', International Studies in the Philosophy of Science 19(1), 31-45. https://doi.org/10.1080/026985905000 51076

McKenzie, R.H., 2011, 'Emergence, reductionism and the stratification of reality in science and theology', Scottish Journal of Theology 64(2), 211-235. https://doi. org/10.1017/S0036930611000068
Meylahn, J.A., 2014, 'Postfoundational practical theology as public Christology', Verbum et Ecclesia 35(2), 1-11. https://doi.org/10.4102/ve.v35i2.875

Moon, Y.B., 2010, 'God as a communicative system sui generis: Beyond the psychic, social, process models of the Trinity', Zygon 45(1), 105-126. https://doi.org/ 10.1111/j.1467-9744.2010.01061.x

Quine, W.V., 1999, 'On what there is', in J. Kim \& E. Sosa (eds.), Metaphysics: An anthology, pp. 4-12, Blackwell Publishing Limited, Oxford.

Russell, B., 1999, 'Existence and description', in J. Kim \& E. Sosa (eds.), Metaphysics: An anthology, pp. 23-35, Blackwell Publishing Limited, Oxford.

The Flower of Life, n.d., viewed 26 May 2017, form https://www.bibliotecapleyades. net/geometria_sagrada/esp_geometria_sagrada_6.htm

Trigg, R., 2015, Beyond matter: Why science needs metaphysics, Templeton Press, West Conshohocken, PA. 